\title{
Plant Growth Parameters in Relationship with Seed Yield of Green Gram Genotypes with Special Reference to Growing Season
}

\author{
Lolesh Pegu* and Prakash Kalita \\ Department of Crop Physiology, AAU, Jorhat-13, India \\ *Corresponding author
}

\begin{abstract}
A B S T R A C T
A study was conducted during kharif and summer seasons of 2013-14 and 2014-15 with twenty genotypes of green gram to study the growth parameters and seed yield of green gram genotypes with special reference to growing season. The mean monthly soil moisture content during crop growing season was 23.46 per cent for kharif season and 12.95 per cent for summer season. The soil was acidic with medium value of organic carbon, low in available N, P and K contents. Significant variations were observed for specific leaf weight, crop growth rate, relative growth rate, net assimilation rate and seed yield among the genotypes and between the seasons. The genotype Pusa Baisakhi was found to be the highest seed yielder during kharif season which was followed by Pant Moong 4, Pratap, SGC 25 and SGC 20. The genotype Pusa Baisakhi showed the highest value for specific leaf weight and total dry matter content. The genotype also showed higher value for crop growth rate, net assimilation rate and relative growth rate which might have contributed towards higher seed yield for this genotype during kharif season. On the other hand, during summer season the genotype SGC 25 was found to be the highest seed yielder followed by SGC 20, Pusa Baisakhi, Pant Moong 4 and Pratap. The genotype SGC 25 showed the higher value for total dry matter content per plant, specific leaf weight, crop growth rate, relative growth rate and net assimilation rate which might have contributed towards higher seed yield for this genotype during summer season. On an average during summer season seed yield was $27.21 \%$ lower compared to that of kharif season which might be due to low soil moisture during summer season. Therefore, the genotype SGC 25 can be adjusted as better genotype for growing in summer season.
\end{abstract}

\section{Keywords}

Green gram, Growth parameters, Seasons, Yield

Article Info

Accepted:

15 February 2020

Available Online:

10 March 2020

\section{Introduction}

Pulses are cheapest source of protein and they serve as a low cost protein to meet the needs of the large section of the people. Green gram (Vigna radiata (L.) Wilczek) is one of the important pulse crops and its seeds contain 24-26 per cent protein, 51 per cent carbohydrate, 4 per cent mineral and 3 per cent vitamins (Mondal et al., 2012). Green gram also plays vital role in fixing large amount of atmospheric nitrogen through root nodules, which helps in improving the fertility status of the soil and thereby helps the succeeding crop. In India green gram occupy an area of about 3.42 million hectares with an 
annual production of about 1.70 million tonnes (Annon, 2013). In Assam green gram is grown both during kharif and summer seasons under rain fed situation. The normal sowing time for kharif green gram in Assam is mid August to mid September whereas for summer green gram it is mid February to mid March. Assam produces around 0.06 lakh tonnes of green gram from an area of 0.12 lakh hectares with a productivity of $5.51 \mathrm{q} / \mathrm{ha}$ (Annon, 2013). Several environmental factors such as acidic soil conditions, rainfall, temperature, soil moisture content etc. are important factors worldwide for leguminous crops.

The genotypes and seasons influence the changes in plant morphology. Mondal et al., (2011) reported that those genotypes which had higher total dry matter, crop growth rate, relative growth rate and net assimilation rate showed higher seed yield in mung bean. They also reported that the interaction effect of season and genotype on yield was significant indicating season had a great influence on growth and yield. Sharma (2014) reported existence of significant differences in morpho-physiological traits like crop growth rate (CGR), relative growth rate (RGR), net assimilation rate (NAR) and leaf characteristics like leaf weight ratio (LWR), leaf shoot ratio (LSR) and leaf area ratio (LAR) for mung bean genotypes. He also opined that NAR, CGR, RGR, SLW and LAR are the desirable traits to explore higher productivity. Therefore, it is necessary to identify the genotype(s) that can fit to the changes in the environmental conditions and minimize the effect of environment on production. Hence, the understanding of plant growth parameters in relationship with seed yield as influence by growing seasons is an essential steps towards identifying suitable genotypes. Keeping the above in view an investigation was carried out to study the growth parameters and seed yield of green gram genotypes with special reference to growing season.

\section{Materials and Methods}

The experiment was carried out in the Instructional-cum-Research Farm and Department of Crop Physiology of Assam Agricultural University, Jorhat during kharif and summer seasons of 2013-14 and 2014-15. The meteorological data during crop grown seasons are presented in Fig. $1 \& 2$. The soil was acidic $(\mathrm{pH} 5.81)$ with medium in organic carbon $(1.38 \%)$ and low phosphorus (19.78 $\mathrm{kg} / \mathrm{ha})$, nitrogen $(236.98 \mathrm{~kg} / \mathrm{ha})$ and potassium $(82.35 \mathrm{~kg} / \mathrm{ha})$ content. The mean monthly soil moisture content during crop growing season was $23.46 \%$ for kharif season and $12.95 \%$ for summer season. Twenty green gram genotypes viz., Pant Moong 4, Pant Moong 5, Pant Moong 6, SGC 2, SGC 20, SGC 25, Pusa Vishal, Pusa Baisakhi, Pusa 9531, Pusa 0672, Pusa 9072, Meha, Pratap, ML 337, HUM 1, PDM 139, PDM 87, PDM 54, PDM 11 and PDM 178 were selected for the study; Pratap being recommended variety for Assam. The genotypes were collected from RARS (Shillongoni), IARI (New Delhi) and I.C.R. Farm of AAU, Jorhat. Seeds were sown directly in rows maintaining a spacing of $30 \times 10 \mathrm{~cm}$. Seed rate, fertilizer dose and other cultural practices were followed as recommended in the package of practice of Assam Agricultural University. The experimental design adopted was Factorial Completely Randomised Design (Factorial CRD) with three replications. The observations on various growth parameters viz., specific leaf weight, crop growth rate, relative growth rate and net assimilation rate were recorded at the beginning of flowering. The observations on total dry matter content per plant and seed yield were recorded at harvest. The experimental data were pooled and statistically analysed and the results of two years pooled data are discussed. 


\section{Results and Discussion}

Leaf thickness is expressed as specific leaf weight. Specific leaf weight refers to dry mass of tissue per unit leaf area. Thicker leaves would have more number of mesophyll cells with high density of chlorophyll and therefore, have a greater photosynthetic capacity than thinner leaves (Craufurd et al., 1999). Thick leaves are associated with high yielding capacities of mung bean and mash bean cultivars (Sharma, 2015). Specific leaf weight, a measure of thickness of leaf has been reported to have a strong positive correlation with leaf photosynthesis in soybean as reported by Bowes et al., (1972). In our present study the twenty green gram genotypes varied significantly in terms of specific leaf weight and the specific leaf weight showed a significant and positive correlation with seed yield $(r=0.82$ and 0.96 respectively for kharif and summer season). Similar results were reported in Indian mustard genotypes by Kaur and Sharma (2015). From the pooled analysis of data we found that the genotype Pusa Baisakhi showed the highest specific leaf weight followed by Pant Moong 4, Pratap, SGC 20 and SGC 25 during kharif season. On the other hand, the genotype Pant Moong 4 and SGC 20 recorded the highest value for specific leaf weight followed by SGC 25, Pusa Baisakhi, Pratap and Meha during summer season. The better performing genotypes in terms of specific leaf weight were also able to record higher values of total dry matter.

Crop growth rate explains the dry matter accumulated per unit land area per unit time (Radford, 1967). The average daily increment in biomass production, namely, crop growth rate is an important useful tool for estimating production efficiency (Ramesh and Ramprasad, 2013). Crop production is determined by CGR as a function of light interception by the leaf area of a crop (Whigham, 1983). Our present results corroborated the findings of Sharma (2014) who reported the existence of significant differences in terms of crop growth rate in mung bean genotypes. Sharma (2014) also opined that crop growth rate is a desirable trait to be exploited for higher productivity. Kaur et al., (2015) reported a significant and positive correlation of crop growth rate with seed yield in Pigeonpea. In our present study also a significant and positive correlation of crop growth rate with seed yield $(r=0.94$ and 0.98 respectively for kharif and summer season) was observed in both the seasons. In our present study, the genotype Pant Moong 4 followed by Pratap, Pusa Baisakhi, SGC 20, Pusa Vishal and SGC 25 recorded the highest value for crop growth rate during kharif season. On the other hand, during summer season the genotype SGC 25 followed by Pant Moong 4, SGC 20, Pusa Baisakhi, Pratap and PDM 139 registered the highest value for crop growth rate.

Relative growth rate shows the amount of dry matter production with respect to the unit weight of the current dry matter of a plant over time (Neumann, 1995). Our result was in close conformity with the findings of Mondal et al., (2012) who found that significant difference in terms of relative growth rate existed among mung bean genotypes and they opined that genotypes which had higher relative growth rate produced higher seed yield. In the present study, a significant and positive correlation was observed between relative growth rate and seed yield $(r=0.86$ and 0.96 respectively for kharif and summer season). In our present study (from pooled analysis) the genotype Pant Moong 4 followed by Pusa Baisakhi, Pratap, SGC 20 and SGC 25 showed the highest values for relative growth rate during kharif season. During summer season also the genotype Pant Moong 4 showed the highest value in terms of 
relative growth rate followed by SGC 25 , SGC 20, Pusa Baisakhi and Pratap.

Net assimilation rate is the net amount of produced dry matters per unit leaf surface area per unit time (Radford (1967). The net assimilation rate is a measure of net photosynthesis of leaves in crop community i.e. it is used as a measure of the rate of photosynthesis minus respiration losses. Significant difference in terms of net assimilation rate was observed among the green gram genotypes. From the correlation study in the present investigation, a significant and positive correlation was observed between net assimilation rate and seed yield $(r=0.93$ and 0.99 respectively for kharif and summer season). In our present study (from pooled analysis) the genotype Pratap was found to record the highest value for net assimilation rate followed by Pant Moong 4, Pusa Baisakhi, SGC 20, SGC 25 and Pusa Vishal during kharif season. On the other hand, during summer season the genotype Pant Moong 4 showed the highest value in terms of net assimilation rate followed by SGC 25, SGC 20, Pusa Baisakhi and Pratap. The higher performer genotypes in terms of net assimilation rate were also found to record higher values of total dry matter, crop growth rate and relative growth rate. Net assimilation rate showed a positive and significant correlation with total dry matter and crop growth rate $(\mathrm{r}=0.96,0.98$ and 0.97, 0.98 respectively for kharif and summer season) in both the seasons.

Khajudparn and Tantasawat (2011) reported that seed yield of mung bean genotypes showed significant and positive correlation with total dry matter. In our present study also the green gram genotypes showed significant and positive correlation between total dry matter content per plant and seed yield $(\mathrm{r}=$ 0.95 and 0.97 respectively for kharif and summer season). In our present study significant variations were observed among the twenty green gram genotypes in terms of total dry matter content. Similar result was reported in black gram genotypes by Malik et al., (2008). In current investigation, from the pooled data we found that the genotype Pusa Baisakhi registered the highest value of total dry matter content per plant followed by Pratap, Pant Moong 4, SGC 20 and SGC 25 during kharif season. On the other hand, during summer season the highest total dry matter content per plant was recorded in the genotype Pant Moong 4 which was followed by SGC 25, Pratap, Pusa Baisakhi and SGC 20.

Our results are in close conformity with the findings of Kumar and Katiyar (2015) who reported that mung bean genotypes showed significant variability for seed yield. In current investigation, from the analysis of pooled data we found that the genotype Pusa Baisakhi registered the highest seed yield during kharif season which was followed by Pant Moong 4, Pratap, SGC 25 and SGC 20. On the other hand, during summer season the genotype SGC 25 registered the highest seed yield followed by SGC 20, Pusa Baisakhi, Pant Moong 4 and Pratap.

Pooled data shown that on an average the plants grown during kharif season recorded $11.98 \%$, 34.64\%, 34.07\%, $28.87 \%$, 35.12\% and $27.21 \%$ higher values respectively for specific leaf weight, crop growth rate, relative growth rate, net assimilation rate, total plant dry matter and seed yield than that of summer season. The decline in values of these parameters during summer season might be due to low soil moisture content i.e. $12.95 \%$ for summer season and $23.46 \%$ for kharif season resulting from differences in rainfall $(82.35 \mathrm{~mm}$ and $208.3 \mathrm{~mm}$ for summer and kharif season respectively). 
Table.1 Specific leaf weight, crop growth rate, relative growth rate, net assimilation rate, total plant dry matter content and seed yield of green gram genotypes during kharif and summer season

\begin{tabular}{|c|c|c|c|c|c|c|c|c|c|c|c|c|c|c|c|c|c|c|}
\hline \multirow[t]{2}{*}{ Genotypes } & \multicolumn{3}{|c|}{$\begin{array}{l}\text { Specific leaf weight } \\
\left(\mathrm{mg} \mathrm{cm}^{-2}\right)\end{array}$} & \multicolumn{3}{|c|}{$\begin{array}{l}\text { Crop Growth rate } \\
\left(\mathrm{g} \mathrm{m}^{-2} \mathbf{d a y}^{-1}\right)\end{array}$} & \multicolumn{3}{|c|}{$\begin{array}{l}\text { Relative growth rate } \\
\left(\mathrm{g} \mathrm{g}^{-1} \text { day }^{-1}\right)\end{array}$} & \multicolumn{3}{|c|}{$\begin{array}{l}\text { Net Assimilation rate } \\
\left(\mathbf{m g ~ c m}^{-2} \mathbf{d a y}^{-1}\right)\end{array}$} & \multicolumn{3}{|c|}{$\begin{array}{l}\text { Total plant dry mater Content } \\
\left(\text { g plant }^{-1}\right)\end{array}$} & \multicolumn{3}{|c|}{$\begin{array}{l}\text { Seed yield } \\
\left(\mathrm{kg} \mathrm{ha}^{-1}\right)\end{array}$} \\
\hline & Kharif & Summer & Mean & Kharif & Summer & Mean & Kharif & Summer & Mean & Kharif & Summer & Mean & Kharif & Summer & Mean & Kharif & Summer & Mean \\
\hline Pant Moong 4 & 8.07 & 6.52 & 7.30 & 17.36 & 10.08 & 13.72 & 0.0443 & 0.0299 & 0.0371 & 0.680 & 0.439 & 0.559 & 27.31 & 17.71 & 22.51 & 1158.66 & 798.38 & 978.52 \\
\hline Pant Moong 5 & 5.86 & 5.62 & 5.74 & 8.65 & 7.23 & 7.94 & 0.0297 & 0.0242 & 0.0269 & 0.375 & 0.331 & 0.353 & 18.30 & 13.30 & 15.80 & 827.65 & 683.95 & 755.80 \\
\hline Pant Moong 6 & 6.25 & 5.97 & 6.11 & 9.87 & 5.96 & 7.92 & 0.0363 & 0.0232 & 0.0297 & 0.429 & 0.297 & 0.363 & 19.39 & 11.57 & 15.49 & 908.35 & 622.95 & 765.65 \\
\hline SGC-2 & 6.27 & 5.93 & 6.10 & 9.30 & 7.36 & 8.33 & 0.0337 & 0.0231 & 0.0284 & 0.455 & 0.342 & 0.399 & 18.99 & 13.93 & 16.46 & 878.91 & 691.63 & 785.27 \\
\hline SGC-20 & 7.54 & 6.52 & 7.03 & 15.13 & 9.74 & 12.44 & 0.0425 & 0.0290 & 0.0357 & 0.633 & 0.428 & 0.531 & 26.17 & 16.12 & 21.15 & 1058.50 & 815.95 & 937.22 \\
\hline SGC-25 & 6.97 & 6.49 & 6.73 & 13.60 & 10.09 & 11.84 & 0.0421 & 0.0296 & 0.0358 & 0.568 & 0.437 & 0.502 & 23.89 & 17.63 & 20.77 & 1080.53 & 823.12 & 951.82 \\
\hline Pusa Vishal & 6.91 & 5.16 & 6.03 & 13.76 & 5.43 & 9.60 & 0.0419 & 0.0203 & 0.0311 & 0.568 & 0.267 & 0.417 & 21.10 & 11.03 & 16.07 & 969.77 & 568.16 & 768.96 \\
\hline Pusa Baisakhi & 8.26 & 6.48 & 7.37 & 16.79 & 9.74 & 13.26 & 0.0440 & 0.0284 & 0.0362 & 0.676 & 0.417 & 0.546 & 29.65 & 16.13 & 22.89 & 1234.57 & 808.55 & 1021.56 \\
\hline Pusa 9531 & 5.96 & 5.35 & 5.66 & 10.32 & 4.63 & 7.47 & 0.0393 & 0.0158 & 0.0275 & 0.428 & 0.246 & 0.337 & 19.58 & 10.56 & 15.07 & 924.37 & 545.44 & 734.91 \\
\hline Pusa 0672 & 5.98 & 5.84 & 5.91 & 9.61 & 7.81 & 8.71 & 0.0348 & 0.0254 & 0.0301 & 0.367 & 0.360 & 0.363 & 19.10 & 14.30 & 16.70 & 897.31 & 703.36 & 800.34 \\
\hline Pusa 9072 & 6.53 & 5.83 & 6.18 & 11.15 & 7.81 & 9.48 & 0.0396 & 0.0234 & 0.0315 & 0.463 & 0.314 & 0.388 & 20.77 & 12.40 & 16.59 & 957.59 & 656.16 & 806.87 \\
\hline Meha & 6.50 & 6.28 & 6.39 & 9.53 & 8.07 & 8.80 & 0.0330 & 0.0271 & 0.0300 & 0.411 & 0.392 & 0.401 & 17.77 & 15.67 & 16.73 & 907.41 & 756.92 & 832.17 \\
\hline Pratap & 7.96 & 6.42 & 7.19 & 16.95 & 9.40 & 13.17 & 0.0439 & 0.0278 & 0.0359 & 0.683 & 0.407 & 0.545 & 27.42 & 16.40 & 21.92 & 1141.30 & 796.91 & 969.10 \\
\hline ML 337 & 6.36 & 4.65 & 5.50 & 8.68 & 5.45 & 7.06 & 0.0308 & 0.0181 & 0.0244 & 0.384 & 0.266 & 0.325 & 18.55 & 10.33 & 14.44 & 797.27 & 580.64 & 688.95 \\
\hline HUM 1 & 6.61 & 4.91 & 5.76 & 12.64 & 5.44 & 9.04 & 0.0416 & 0.0184 & 0.0300 & 0.525 & 0.260 & 0.392 & 21.48 & 11.42 & 16.45 & 971.12 & 608.32 & 789.72 \\
\hline PDM 139 & 5.62 & 5.71 & 5.66 & 9.42 & 8.87 & 9.14 & 0.0332 & 0.0265 & 0.0298 & 0.400 & 0.374 & 0.387 & 18.37 & 15.27 & 16.82 & 782.21 & 732.75 & 757.48 \\
\hline PDM 87 & 5.72 & 4.45 & 5.08 & 8.40 & 4.83 & 6.61 & 0.0271 & 0.0152 & 0.0211 & 0.378 & 0.237 & 0.308 & 18.62 & 10.03 & 14.33 & 864.71 & 540.46 & 702.58 \\
\hline PDM 54 & 5.78 & 6.07 & 5.92 & 12.11 & 8.17 & 10.14 & 0.0348 & 0.0259 & 0.0304 & 0.448 & 0.368 & 0.408 & 20.71 & 14.58 & 17.65 & 961.15 & 721.10 & 841.13 \\
\hline PDM 11 & 5.59 & 5.66 & 5.63 & 7.89 & 6.93 & 7.41 & 0.0270 & 0.0238 & 0.0254 & 0.357 & 0.320 & 0.338 & 17.49 & 12.83 & 15.16 & 882.32 & 666.72 & 774.52 \\
\hline PDM 178 & 5.54 & 4.70 & 5.12 & 7.47 & 6.31 & 6.89 & 0.0236 & 0.0202 & 0.0219 & 0.330 & 0.307 & 0.319 & 16.15 & 11.74 & 13.95 & 711.72 & 645.85 & 678.78 \\
\hline \multirow[t]{2}{*}{ Mean } & 6.51 & 5.73 & & 11.43 & 7.47 & & 0.0361 & 0.0238 & & 0.478 & 0.340 & & 21.04 & 13.65 & & 945.77 & 688.36 & \\
\hline & SEm \pm & SEd \pm & CD-5\% & SEm \pm & SEd \pm & CD-5\% & SEm \pm & SEd \pm & CD-5\% & SEm \pm & SEd \pm & CD-5\% & SEm \pm & SEd \pm & CD-5\% & SEm \pm & SEd \pm & CD-5\% \\
\hline Variety (V) & 0.068 & 0.097 & 0.196 & 0.165 & 0.234 & 0.474 & 0.0007 & 0.001 & 0.002 & 0.006 & 0.008 & 0.017 & 0.191 & 0.270 & 0.548 & 7.485 & 10.585 & 21.473 \\
\hline Season $(\mathbf{S})$ & 0.217 & 0.306 & 0.621 & 0.523 & 0.739 & 1.499 & 0.002 & 0.003 & 0.006 & 0.019 & 0.026 & 0.054 & 0.604 & 0.854 & 1.732 & 23.669 & 33.474 & 67.902 \\
\hline $\mathbf{V} \times \mathbf{S}$ & 0.306 & 0.433 & 0.878 & 0.739 & 1.045 & 2.120 & 0.003 & 0.004 & 0.008 & 0.026 & 0.037 & 0.076 & 0.854 & 1.208 & 2.450 & 33.474 & 47.339 & 96.028 \\
\hline
\end{tabular}


Figure.1 Meteorological data during Kharif, 2013 and Summer, 2014

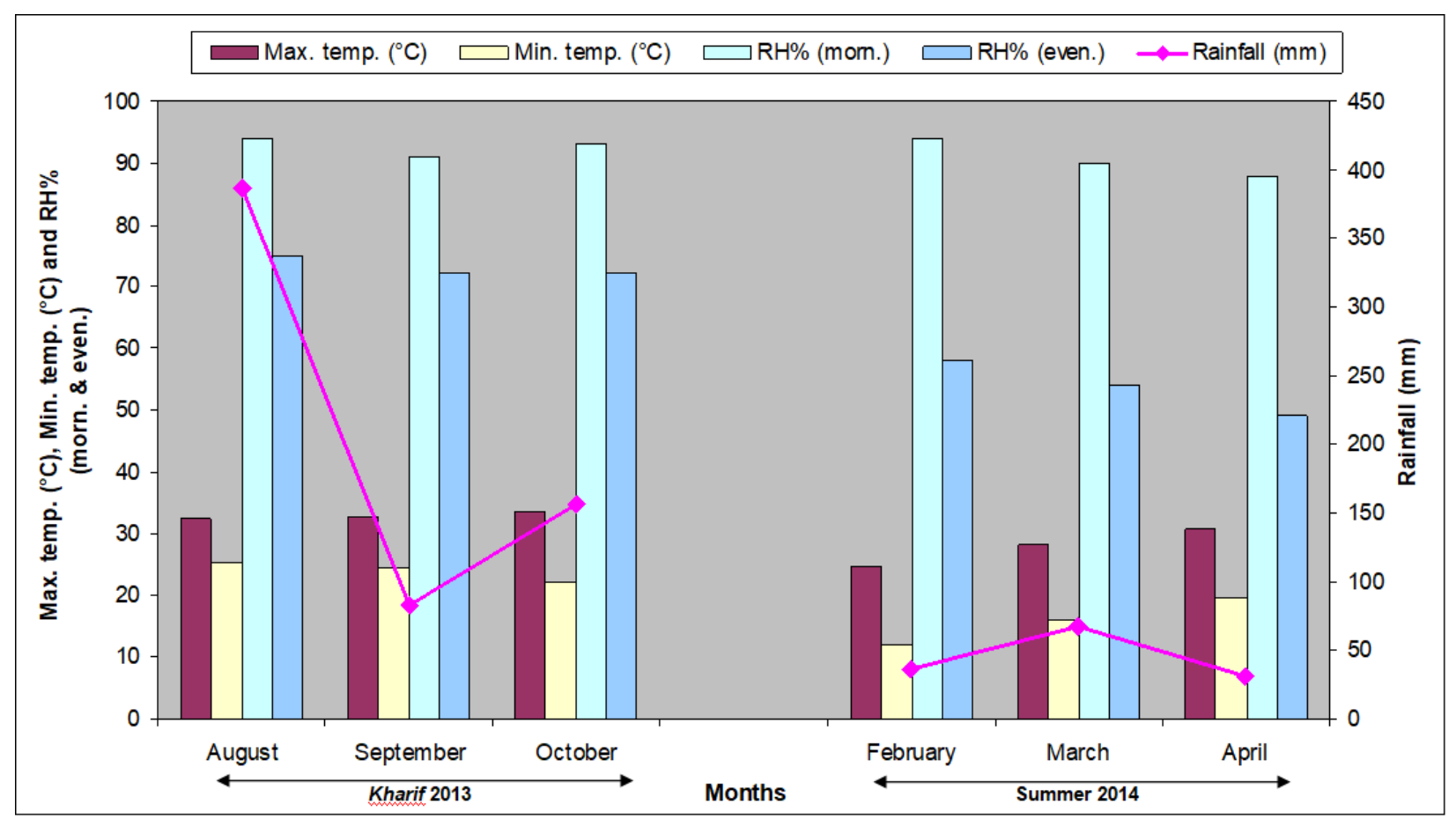

Figure.2 Meteorological data during Kharif, 2014 and Summer, 2015

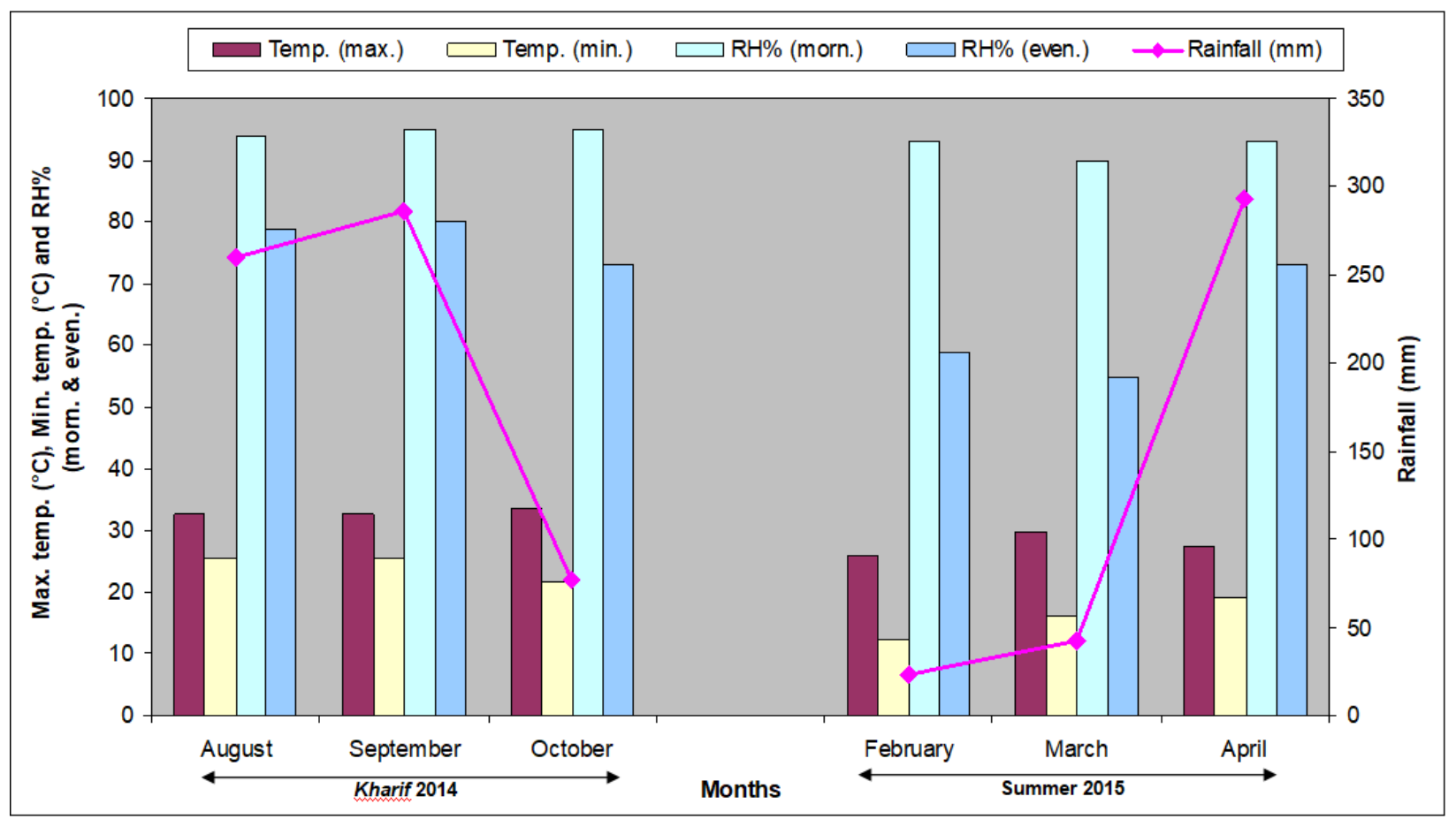


Sharma (2015) also reported that moisture stress hampered the growth significantly resulting in reduced specific leaf weight and crop growth rate in mung bean and mash bean cultivars and he also opined that the reduction in these parameters under water deficit stressed condition could be related to lesser number of mesophyll cells leading to lower photosynthetic efficiency. The higher relative growth rate during kharif season might be related to the ability of plants to produce higher leaf area (data not shown) and the ability of plants to maintain better photosynthesis under adequate soil moisture content that contributes to the accumulation of higher amount of dry matter. Madukwe et al., (2011) reported that net assimilation rate was higher in the mung bean plants where sufficient water was supplied as compared to that of water limited plants and this could be an indication that the photosynthetic activities per unit leaf area in the well water supplied plants were more than that of the plants where water was limited. The lower value of total plant dry matter and seed yield during summer season might be due to low soil moisture regime. The lower seed yield under low soil moisture regime might be due to reduction in specific leaf weight, crop growth rate, relative growth rate, net assimilation rate and total plant dry matter.

In conclusion, the genotype Pusa Baisakhi was found to be the highest seed yielder during kharif season. The genotypes namely Pant Moong 4, Pratap, SGC 25 and SG 20 were also found to be higher seed yielder during kharif season. On the other hand, the genotype SGC 25 was found to be the highest seed yielder during summer season followed by SGC 20, Pusa Baishaki, Pant Moong 4 and Pratap. On an average during kharif season $27.21 \%$ higher seed yield could be obtained compared to that of summer season. Therefore, the genotype SGC 25 can be adjudged as the better genotype for growing in summer season. The parameters viz., specific leaf weight, crop growth rate, relative growth rate and net assimilation rate appear to be the major contributing factors for higher yield performance of this genotype during summer season in view of the soil moisture deficit situation that normally prevail during that period under Assam condition in addition to the constraint arising out of soil acidity.

\section{References}

Annon. 2013. Project Coordinators Report, All India Coordinated Research Project on MULLARP (ICAR). Indian Institute of Pulses Research, Kanpur: 26.

Annon. 2013. Economic Survey of Assam, 2011-12

Bowes, G.W., Orgen, L. and Hageman, R.H. 1972. Light saturated photosynthesis rate, $\mathrm{RuBP}$ carboxylase activity and specific leaf weight in soybeans grown under different light intensities. Crop Sci. 12: 77-79.

Craufurd, P.C., Wheeler, T.R., Ellis, R.H., Summer, R.J. and Williams, J.H. 1999. Effect of temperature and water deficit on water use efficiency, carbon isotope discrimination and specific leaf area in peanut. Crop Sci. 39: 136-142.

Kaur, G., Ghai, N., Kaur, J. and Singh, S. 2015. Growth efficiency and yield of pigeonpea (Cajanus cajan L.) as affected by foliar application of mineral nutrients. J. Plant Sci. Res. 2(2): 130.

Kaur, S. and Sharma, P. 2015. Correlation between leaf traits and moisture availability in Indian mustard (Brassica juncea L.). Appld. Biol. Res. 17(2): 174184.

Khajudparn, P. and Tantasawat, P. 2011. Relationships and variability of agronomic and physiological characters in mungbean. African J. Biotechnol. 10(49): 9992-10000.

Kumar, S. and Katiyar, M. 2015. Genetic 
variability, heritability, expected genetic advance and character association in mungbean [Vigna radiata L. (Wilczek)]. Int. J. Adv. Res. 3(5): 13711375 .

Madukwe, D.K., Ibe, A.E., Onuh, M.O. and Christo, I.E. 2011. Effects of water stress on the performance of mungbean (Vigna radiata (L.) Wilczek) in southeastern Nigeria. Int. Sci. Res. J. 3: 56-60.

Madukwe, D.K., Ibe, A.E., Onuh, M.O. and Christo, I.E. 2011. Effects of water stress on the performance of mungbean (Vigna radiata (L.) Wilczek) in southeastern Nigeria. Int. Sci. Res. J. 3: 56-60.

Malik, M.F.A., Awan, S.I. and Naiz, S. 2008. Comparative study of quantitative traits and association of yield and its components in black gram (Vigna mungo) genotypes. Asian J. Plant Sci. 7(1): 26-29.

Mondal, M.M.A., Fakir, M.S.A., Islam, M.N. and Samad, M.A. 2011. Physiology of seed yield in mungbean: growth and dry matter production. Bangladesh J. Bot. 40(2): 133-138.

Mondal, M.M.A., Puteh, A.B., Malek, M.A., Ismail, M.R., Rafii, M.Y. and Latif,
M.A. 2012. Seed yield of mungbean (Vigna radiata (L. wilczek) in relation to growth and developmental aspects. Sci. World J. 2012(2): 1-7.

Neumann, P.M. 1995. The role of cell wall adjustment in plant resistance to water deficits. Crop Sci. 35: 1258-1266.

Radford, P.J. 1967. Growth analysis formulae-their use and abuse. Crop Sci. 7: 171-175.

Ramesh, R. and Ramprasad, E. 2013. Effect of plant growth regulators on morphological, physiological and biochemical parameters of soybean (Glycine max 1. Merrill). Helix 6: 441447.

Sharma, P. 2014. Performance of mungbean under irrigated conditions: Physiological parameters determining the yield during crop growth. J. Pl. Sci. Res. 30(2): 147-152.

Sharma, P. 2015. Growth dynamics and leaf characteristics of pulse under water deficit and irrigation regimes. Ann. Plant Soil Res. 17(2): 150-155.

Whigham, D.K. 1983. Soybean. In: Proc. of symposium on potential productivity of field crops under different environment. IRRI, Los. Banos. 22(26): 205-225.

\section{How to cite this article:}

Lolesh Pegu and Prakash Kalita. 2020. Plant Growth Parameters in Relationship with Seed Yield of Green Gram Genotypes with Special Reference to Growing Season. Int.J.Curr.Microbiol.App.Sci. 9(03): 2131-2138. doi: https://doi.org/10.20546/ijcmas.2020.903.243 